\title{
International Journal of Ayurveda and Pharma Research
}

\author{
Case Study
}

\section{MANAGEMENT OF BUERGER'S DISEASE THROUGH AYURVEDA- A CASE REPORT}

\section{Shikha Chaudhary ${ }^{*}$, Divya Kajaria ${ }^{2}$, Rama Kant Yadava ${ }^{3}$}

${ }^{*}$ MD Scholar, ${ }^{2}$ Assistant Professor, ${ }^{3}$ Associate Professor, Department of Kayachikitsa, All India Institute of Ayurveda, New Delhi, India.

\begin{abstract}
The present case report was about a 50 year-old-male who was diagnosed with Buerger's disease which is a generalised occlusive vascular disease affecting predominantly males with special predilection to involve the lower extremities. He presented with complaint of unhealed ulcerations with pain and burning sensation in his right sole for 6 months but not getting satisfactory relief even after using conventional medications and advised to get done amputation. He visited the All India institute of Ayurveda and was treated for two months with a combination of Ayurvedic medicines and leech therapy which showed significant improvement in patients condition and eventually no recurrence was observed, ulcer healed completely with slight discolouration. This shows the effectiveness of Ayurvedic treatment including internal medicines administration and leech therapy in preventing amputation and treating other symptoms which may be useful for clinical practices.
\end{abstract}

KEYWORDS: Buerger's disease, Ayurveda, Medicinal Leech therapy (MLT).

\section{INTRODUCTION}

Buerger's disease, also known as Thromboangitis obliterans (TAOs), is a rare disease of the arteries and veins in the arms and legs. It is an inflammatory occlusive vascular disorder involving small and medium-sized arteries and veins in the distal upper and lower extremities. It is more common among men than women. The disease is found worldwide, but the highest incidence of Thromboangiitis obliterans occurs in the Middle and Far East. The prevalence is higher in Asians and individuals of Eastern European descent. Although the cause of Thromboangiitis obliterans is not known, there is a definite relationship to cigarette smoking in patients with this disorder. The prevalence of the disease among all patients with peripheral arterial disease ranges from values as low as 0.5 to $5.6 \%$ in Western Europe to values as high as 45 to $63 \%$ in India, 16 to $66 \%$ in Korea and Japan, and $80 \%$ among Jews of Ashkenazi ancestry living in Israel. Part of this variation in disease prevalence may be due to variability in diagnostic criteria.[1] There are no accurately defined treatments for TAO at present.[2] TAO remains a systemic vasculitis strangely linked to smoking, which determines its occurrence, progression and prognosis by currently unknown mechanisms. Except for discontinuation of tobacco use, there is no other definitive therapy. ${ }^{[3]}$

\section{Case History}

A 50 years old Indian, married, non-alcoholic male with a 20-year history of heavy cigarette smoking (UHID No. 333435) visited the Out-patient Department of Kayachikitsa (unit Rheumatology)at All India Institute of Ayurveda, New Delhi complaint of wound over little finger of right foot, presented with unhealed ulcerations with pain and burning sensation in right sole for 6 months. He had no history of foreign travel and familial problems. He was afebrile without history of trauma, allergies, or systemic disease. After smoking cessation and the oral administration of colchicine $(0.5 \mathrm{mg})$, prednisolone $(10 \mathrm{mg})$, hydroxycholoroquine (400 mg), and mycophenolic acid (360 mg), his wound healing response was still poor.

Arterial Doppler B/L lower Limbs; defuse significant right ATA/PTA disease with parvus trades waveforms.

MR ANGIO Aorta and B/L Lower Limbs showed complete occlusion of right tibioperoneal trunk with poor distal reformation.

Carotid Doppler was normal.

\section{Clinical Findings}

In the presence of severe digital ischemia, trophic nail changes, painful ulcerations, and gangrene developed at the tip of the ring and little toes in the present case. 
Int. J. Ayur. Pharma Research, 2020;8(8):65-68

The pulsation of the bilateral dorsalis pedis arteries was normal in the physical examination. However, the computed tomography angiography showed occlusions of the bilateral posterior tibialis arteries at the level of the ankles. The patient's white blood cell and eosinophil counts, renal and liver function, immunoglobulin G, D-dimer, antiphospholipid antibodies, and anti-neutrophil cytoplasmic antibodies were all normal. Skin biopsy from the little finger not done.

Treatment modalities planned on the basis of condition tabulated in Table 1 . Along with Internal medications, MLT was performed. Timeline has been shown in table 2. Comparison was done before and after treatment and tabulated in Table 3.

Table 1: Showing Interventions used with timeline

\begin{tabular}{|l|l|l|l|l|}
\hline Intervention & Medicines Administered & Dose & Frequency & Duration \\
\hline \multirow{5}{*}{ Oral } & Kaisor guggulu & $500 \mathrm{mg}$ & BID & 15 days \\
\cline { 2 - 5 } & Triphala guggulu & $500 \mathrm{mg}$ & BID & 15 days \\
\cline { 2 - 5 } & Dashmool Haritaki Avleha & $10 \mathrm{gm}$ & BID & Next 15 days \\
\cline { 2 - 5 } & $\begin{array}{l}\text { Mahamanjisthadi Kwath }+ \\
\text { Guduchi churna }\end{array}$ & $20 \mathrm{ml}+3 \mathrm{gm}$ & BID & 30 days \\
\cline { 2 - 6 } & Khadirarista & $15 \mathrm{~mL}$ & BID & 30 days \\
\hline \multirow{5}{*}{ Topical } & $\begin{array}{l}\text { Panchvalkal Kwath }+ \\
\text { Sphatik bhasma }\end{array}$ & Q. S. & BID & 15 days \\
\cline { 2 - 6 } & Jatyadi taila & Q. S. & BID & 30 days \\
\hline
\end{tabular}

Table 2: Leech Therapy Schedule

\begin{tabular}{|l|l|l|}
\hline Blood Letting & Site & Duration \\
\hline Baseline & Right foot 4th web space & 30 mins \\
\hline After 7 days & Right foot 1st and 4th web space & 30 mins \\
\hline After 15 days & $\begin{array}{l}\text { Back of 4th web space and 10 inch } \\
\text { above the right popliteal region }\end{array}$ & 40 mins \\
\hline
\end{tabular}

Table 3: BT and AT Comparison

\begin{tabular}{|l|l|l|l|l|}
\hline Domain & Method & BT VAPR & After 10 days & After 15 days \\
\hline Pain & VAS & 8 & 6 & 1 \\
\hline Claudication distance & & $70 \mathrm{mts}$. & $110 \mathrm{mts}$. & $>200 \mathrm{mts}$. \\
\hline Distal pulses (ATA, PTA, PA) & & Not palpable & Not Palpable & Feeble \\
\hline
\end{tabular}

ATA: Anterior Tibial Artery, PTA: Posterior Tibial Artery, PA: Peroneal artery

Table 4: Probable mode of action of Leech on TAO

\begin{tabular}{|l|l|}
\hline Substance of leech & Action \\
\hline Hirudin & $\begin{array}{l}\text { Reduces factor VIII of coagulation allowing blood to flow freely } \\
\text { and reduces hyper coagulation }\end{array}$ \\
\hline Apyrase (Platelet anti-aggregate factor) & Thrombus destruction \\
\hline Eglin (Anti-inflammatory) & Reduces the inflammatory process in the vessels \\
\hline Bdellin (A protease inhibitor) & $\begin{array}{l}\text { Dissolve foreign protein matrix and digests undue intimal wall } \\
\text { of the blood vessel }\end{array}$ \\
\hline Hyalurodinase & Diffuses the blood for free. Flow \\
\hline Histaminase & Produces vasodilation action and promotes regeneration \\
\hline Esterase (lipolytic substance) & Prevents hyper coagulation and reduces fat flow \\
\hline
\end{tabular}




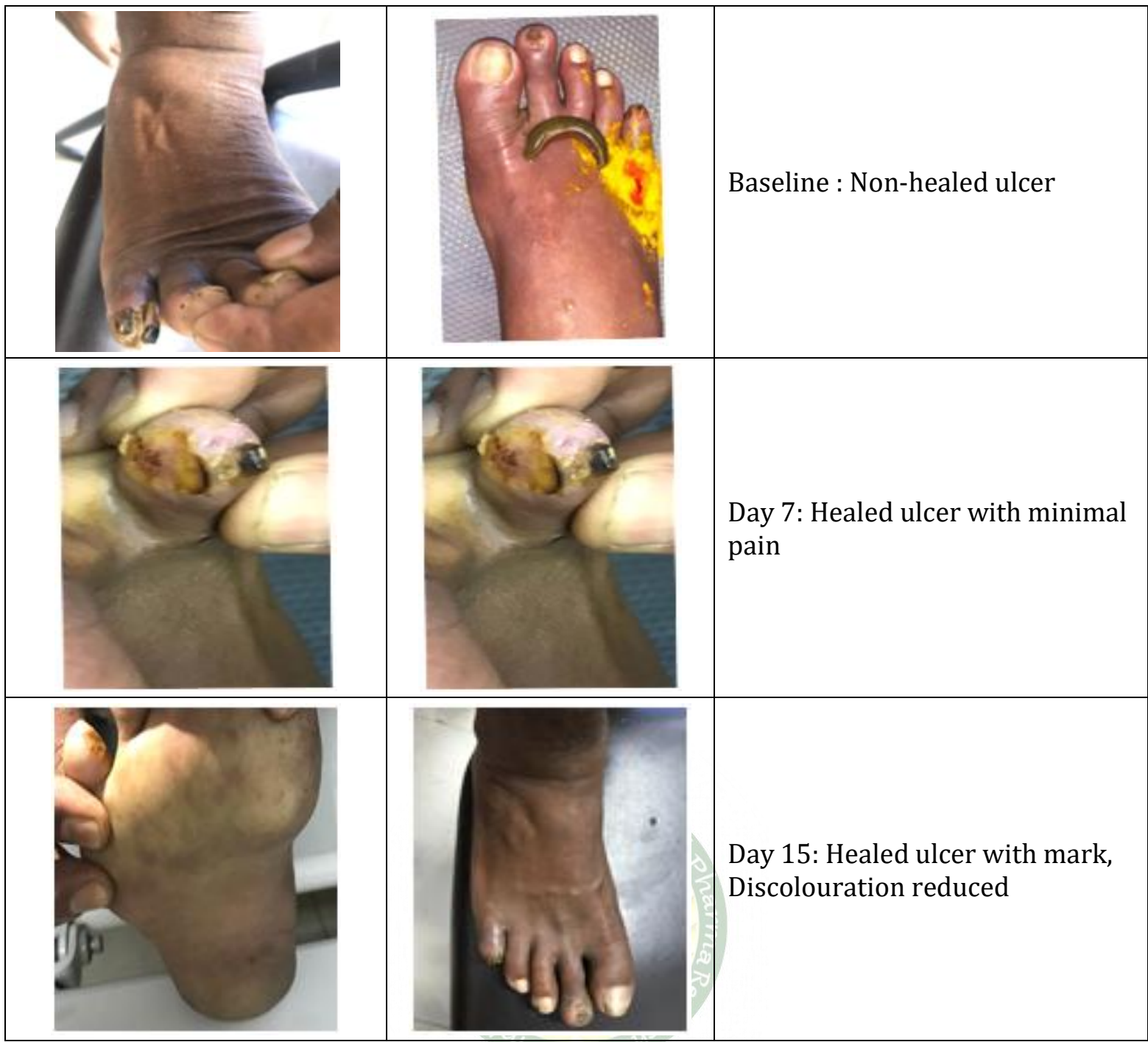

\section{DISCUSSION}

Many treatments of TAO include prostacyclin, growth factors, sympathectomy, and surgical revascularization. Unfortunately, there is no accurately defined treatment. ${ }^{[4]}$ There is no specific treatment except abstention from tobacco. The prognosis is worse in individuals who continue to smoke, but results are discouraging even in those who stop smoking. Arterial bypass of the larger vessels may be used in selected instances, as well as local debridement, depending on the symptoms and severity of ischemia. Antibiotics may be useful; anticoagulants and glucocorticoids are not helpful. If these measures fail, amputation may be required[5]. Amputation of a digit or a part is indicated when an ulcer refuses to heal, severe pain restricted to the affected digit and gangrene limited to the toe.

In present case study, the ulcer of patient was not healing inspite of tobacco stop and conservative medications. Along with internal medicine, MLT was planned to be done. The probable mode of action of MLT on TAO tabulated in table No. 04. The basis of MLT is to correct the pathological and hemodynamic disturbances and as well as to restore the normal circulation in the affected limb which showed encouraging improvement in the present case, may be due to the possible synergistic action of leech enzymes which being capable of nullify the pathological sequence of TAO.

Based on sign and symptoms Buerger disease can be co related with Vatarakta. So local and systemic treatment was given to the patient as per text (explained under Vatarakta chapter). According to Ayurvedic concept pain occurs due to vitiation of Vatadosha, burning sensation occur due to Pittadosha and pus occur due to Kaphadosha. Panchavalkala Kwath and Sphatikbhasma was used for local wash followed by application of Jatyaditail. Panchavalkala Kwath pacifies Vata-kapha and having properties like Vranaprakshalana, Vranaropana and Shothahara. Sphatikbhasma mainly have Shodhana, Stambhana, Shothahara (anti-inflammatory) and Vedanahara (Analgesic) properties, which helped to relieve pain, local edema as well as to stop oozing and maintained local hygiene. Jatyaditaila was applied after wash on the affected part for soothing, and healing effect. Phytochemical evaluation of Jatyaditaila revealed 
presence of flavonoids, essential oils, tannins, glycosides and alkaloids while resins were found to be absent. HPTLC confirmed the presence of Karanjin, lupeol Jatyadi tailam. Jatyadi tailam was found to be non-irritant.[5]

For systemic treatment Kaishorguggulu and Triphalaguggulu balances Pitta and Kapha, particularly when it affects musculoskeletal system. Both create a detoxifying and rejuvenating effect aimed primarily at removing deep seated Pitta and Kapha from the tissues.

Mahamanjisthadikwath (MK) along with Giloychurn was given. MK is a classical Ayurvedic combination detailed in the context of Vatarakta in Sahasrayoga. The combination has a broad spectrum of activity ranging from Astadasa kusta (a wide spectrum of skin diseases), Vatarakta (rheumatoid arthritis), Arditha (bell's palsy) Upadamsa (veneral diseases), Sleepada (filariasis), Prasupthi (numbness), Pakshaghat (hemiplegia), Medodosha (diseases related to fatty depositions) etc. While Giloychurna having properties like anti-inflammatory, anti arthritic, anti allergic, anti oxidant, hepato-protective, immunomodulative and cardioprotective activity.[6]

Khadirarishta used to correct discolouration while Dashmoolharitakiavleha used to maintain the effect as it has rejuvenating as well as Srotoshodhan activity.

\section{CONCLUSION}

The combined Ayurvedic treatment of prescribed medications along with parasurgical procedure viz. Leech therapy were promisingly helpful in treating the case of burger's disease. This approach may be useful for clinical practices and may be taken into consideration for further research work.

\section{ACKNOWLEDGEMENT}

Author is highly thankful to Dr.Jyoti, Dr.Gunjan, Dr.Mythri for providing help in leech therapy.

\section{REFERENCES}

1. Perttu ET Arkkila, Thromboangiitis obliterans (Buerger's disease), Orphanet Journal of Rare Diseases, 2006; 1: 14.

2. Rivera-Chavarría IJ, Brenes-Gutierrez JD. Thromboangiitis obliterans (Buerger's disease). Ann Med Surg (Lond) 2016;7:79-82.

3. X.Puechal, J.-N.Fiessinger Thromboangiitis obliterans or Buerger's disease: challenges for the rheumatologist. Rheumatology, Volume 46, Issue 2, February 2007, Pages 192-199.

4. Kasper, Fauci et Al. Harrison's Principles of internal medicine, 19th edition, Chapter 302. Page no. $1645-1646$.

5. Sunita Shailajan et al. wound healing efficacy of Jatyadi Taila: In vivo evaluation in rat using excision wound model, Journal of ethnopharmacology 138(1):99-104 - August 2011, DOI: 10.1016/j.jep.2011.08.050.

6. Avnish K. Upadhyay et Al. Tinospora cordifolia (Willd.) Hook. f. and Thoms. (Guduchi) - validation of the Ayurvedic pharmacology through experimental and clinical studies, Int J Ayurveda Res. $2010 \quad$ Apr-Jun; 1(2): 112-121, doi: 10.4103/0974-7788.64405.

\section{Cite this article as:}

Shikha Chaudhary, Divya Kajaria, Rama Kant Yadava. Management of Buerger's Disease through Ayurveda- A Case Report. International Journal of Ayurveda and Pharma Research. 2020;8(8):65-68.

Source of support: Nil, Conflict of interest: None Declared
*Address for correspondence Dr. Shikha Chaudhary

MD Scholar

Department of Kayachikitsa, All India Institute of Ayurveda, New Delhi, India.

Email: shikhachaudhary08@icloud.com Ph. No.: 9205109463

Disclaimer: IJAPR is solely owned by Mahadev Publications - dedicated to publish quality research, while every effort has been taken to verify the accuracy of the content published in our Journal. IJAPR cannot accept any responsibility or liability for the articles content which are published. The views expressed in articles by our contributing authors are not necessarily those of IJAPR editor or editorial board members. 